\title{
Glucagon receptors on human islet cells contribute to glucose competence of insulin release
}

\author{
P.Huypens, Z. Ling, D. Pipeleers, F. Schuit \\ Diabetes Research Centre, Faculty of Medicine, Vrije Universiteit Brussel, Brussels, Belgium
}

\begin{abstract}
Aims/hypothesis. Synergism between glucose and cAMP in the stimulation of insulin secretion has been suggested to regulate beta cells. This study assessed the importance of an interaction between glucose and cAMP in the stimulation of insulin secretion from human islet cells by investigating expression and functional activity of receptors recognising glucagon, glucagon-like peptide-1 (7-36)amide (GLP-1) and glucose-dependent insulinotropic polypeptide (GIP). Methods. Expression of the glucagon, GLP-1 and GIP receptors in human islets was investigated by northern blots and reverse transcription-polymerase chain reaction analysis. Functional activity of these receptors was assessed by the effects of peptides (agonists and antagonists) on glucose-induced insulin release.
\end{abstract}

Results. Human islet cells express transcripts encoding glucagon, GLP-1 and GIP receptors. Glucose
(10 mmol/l) stimulated insulin release $4.5 \pm 0.6$-fold over basal $(2.5 \mathrm{mmol} / \mathrm{l})$. This glucose effect was amplified by $10 \mathrm{nmol} / \mathrm{l} \mathrm{GLP}-1$, GIP or glucagon. It was reduced by $51 \pm 6 \%$ in the presence of $1 \mu \mathrm{mol} / \mathrm{l}$ of the glucagon-receptor antagonist des-His ${ }^{1}-\left[\mathrm{Glu}^{9}\right]-$ glucagon-amide $(n=8 ; p<0.05)$, indicating participation of endogenously released glucagon in the process of glucose-induced insulin release. The glucagon-receptor antagonist also suppressed the potentiation of glucose-induced insulin release by addition of $10 \mathrm{nmol} / \mathrm{l}$ glucagon.

Conclusion/interpretation. These data suggest that human beta cells express functional glucagon receptors which can, similar to incretin hormone receptors, generate synergistic signals for glucose-induced insulin secretion. [Diabetologia (2000) 43: 1012-1019]

Keywords Glucagon receptors, GLP-1 receptors, GIP receptors, beta cells, cyclic AMP, insulin, diabetes, glucose competence
Previous studies on rat beta cells in vitro have suggested that insulin release is synergistically regulated by signalling molecules derived from glucose metabolism on the one hand and adenylate cyclase stimulation by glucagon or related peptides on the other [1-3]. In rodent beta cells, regulation of the cAMP-

Received: 7 February 2000 and in revised form: 24 March 2000

Corresponding author: F. Schuit, Department of Biochemistry, Diabetes Research Center, Vrije Universiteit Brussel, Laarbeeklaan 103, B-1090 Brussels, Belgium

Abbreviations: GIP, glucose-dependent insulinotropic polypeptide; R, receptor; GLP-1, glucagon-like peptide-1-(7-36)amide. dependent signalling pathway has been shown [3-7] to depend on expression of specific receptors for glucagon-like peptide-1-(7-36) amide (GLP-1), glucosedependent insulinotropic polypeptide (GIP) and glucagon. The gastrointestinal hormones GLP-1 and GIP effectively increase glucose-induced insulin release in vitro [8-10]; their pivotal role as incretin hormones has been recently illustrated in two mouse models with homozygous null mutations in the respective genes $[11,12]$. It is not clear whether similar mechanisms operate in human beta cells. More than three decades ago insulin release in humans was shown to be dually stimulated by glucose and glucagon $[13,14]$, the glucagon effect appearing independent of enhanced glucose mobilisation from the liver 
[15]. Insulin release from isolated human islets was also found to be stimulated by glucose and by phosphodiesterase inhibitors [16, 17]. Therefore, similar as was proposed for the rat [1-3], synergism between glucose metabolism and intracellular cAMP concentrations in the regulation of insulin release from human beta cells could be present. Such signalling could be clinically relevant because defects in one of the components of beta-cell signalling in response to glucose or to cAMP could be involved in the pathophysiology of human diabetes [18]. While studying insulin release from isolated human islet preparations, we noticed similarities to and differences from glucose regulation in rodent beta cells [17, 19, 20]. We have extended this investigation to the cAMP-generating component of beta-cell regulation. Studies in vivo have shown that glucagon [14-16] as well as the gluco-incretins GLP-1 and GIP [21-24] stimulate insulin secretion in human subjects. As the human genes encoding GLP-1 receptor (R), GIP-R and glucagon receptor have been cloned [25-27], we studied receptor gene expression in isolated human islet cells, assessing the presence of mRNA and the functional importance of these receptors for glucose competence in human beta cells. For the glucagon receptor, receptor function was evaluated using des-His ${ }^{1}$-[Glu $\left.{ }^{9}\right]$-glucagon-amide, a specific receptor antagonist [28]. Our data show that glucagon receptors contribute substantially (more than $50 \%$ ) to the glucose-induced secretory responsiveness of human islet cells.

\section{Materials and methods}

Preparation and culture of human islet cells. Human pancreatic tissue, isolated islets and duct cells were obtained as samples for analysis from a multicentre programme on betacell transplantation in diabetes [17], which was approved by central and local ethical committees. Total RNA for RT-PCR analysis was extracted from tissue samples taken during autopsies within $8 \mathrm{~h}$ of death. Islet cell preparations were isolated from 12 different pancreata, (donor age 9-56 years) the most frequent causes of death of the donors (all nondiabetic) being intracranial haemorrhage (6/12) and severe head trauma (2/12). Donor organs were procured at European hospitals affiliated with Eurotransplant (Leiden, The Netherlands) and Beta-Cell Transplant (Brussels, Belgium). Cold preservation time of the organs was $13.5 \pm 1.9 \mathrm{~h}$ (means $\pm \mathrm{SEM}$ ). Islets were prepared as described previously [17], the mean duration of isolation being $5 \mathrm{~h}$, and then cultured for 2 to 5 days in Ham's F10 medium, containing $6.1 \mathrm{mmol} / \mathrm{l}$ glucose [17]. After dissociation of cultured islet preparations, more than $90 \%$ of the cells stained positive for the vital stain neutral red; they comprised $53 \pm 8 \%$ insulin-positive cells $15 \pm 3 \%$ glucagon-positive cells and $38 \pm 15 \%$ non-granulated duct cells. Dispersed human islet cells were distributed over Multiwells (Falcon, Becton Dickinson, N.J., USA) and cultured for 1 day in serum-free Ham's F10 medium containing 1\% BSA (fraction V, RIA grade, Sigma, St. Louis, Mo., USA), $0.075 \mathrm{mg} / \mathrm{ml}$ penicillin and $0.1 \mathrm{mg} / \mathrm{ml}$ streptomycin, $6.1 \mathrm{mmol} / 1$ glucose and $2 \mathrm{mmol} / \mathrm{l}$ glutamine. Under this condition, islet cells formed small clumps (three to ten cells) and attached loosely to the bottom.
Nongranulated duct cells were prepared and cultured as described [29]. The final preparation was $90 \%$ or more pure with less than $5 \%$ contaminating endocrine or acinar cells.

Measurement of insulin release. Cultured islet cells were washed with glucose free Ham's F10 medium containing 1\% BSA and $2 \mathrm{mmol} / \mathrm{l}$ glutamine and distributed over Multiwells as batches of $2.5 \times 10^{4}$ cells. They were then statically incubated for $2 \mathrm{~h}$ at $37^{\circ} \mathrm{C}$ in $95 \%$ air:5\% $\mathrm{CO}_{2}$ with $1 \mathrm{ml}$ Ham's F10 medium containing $1 \% \mathrm{BSA}$ and $2 \mathrm{mmol} / \mathrm{l}$ glutamine supplemented with 2.5 or $10 \mathrm{mmol} / \mathrm{l}$ glucose, with or without addition of glucagon, GLP-1 or GIP $(10 \mathrm{nmol} / \mathrm{l})$ or the presence of the glucagon-receptor antagonist des-His ${ }^{1}-\left[\mathrm{Glu}^{9}\right]$-glucagonamide $\left(1 \mu \mathrm{mol} / \mathrm{l}\right.$; [28]). Glucagon, GLP-1, GIP and des-His ${ }^{1-}$ $\left[\mathrm{Glu}^{9}\right]$-glucagon-amide were purchased from Sigma. The GLP-1R antagonist exendin-(9-39)-amide [30] was kindly provided by Dr. J. Vandekerckhove (Department of Physiological Chemistry, University of Ghent, Belgium). At the end of incubation, supernatant was taken for insulin immunoassay and cell pellets were extracted for assessment of insulin content [17]. Insulin was expressed as per cent of insulin content. No difference in insulin content was observed after incubation of islet cells in 2.5 or $10 \mathrm{mmol} / \mathrm{l}$ glucose $(0.25 \pm 0.04 \mu \mathrm{g} / \mathrm{well}$ and $0.27 \pm 0.04 \mu \mathrm{g} /$ well, respectively $n=6$ ).

$m R N A$ analysis. Total RNA was isolated from human control tissues and human islet cells using Gibco BRL TRIzol (Life Technologies, Merelbeke, Belgium). Qualitative RT-PCR analysis of the expression of GLP-1R, GIP-R and glucaconreceptor mRNA in human islet cells was done by reverse tran-

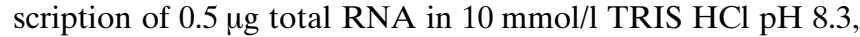
$50 \mathrm{mmol} / \mathrm{l} \mathrm{KCl}, 5 \mathrm{mmol} / 1 \mathrm{MgCl}_{2}$ with $1 \mathrm{mmol} / \mathrm{l}$ deoxyribonucleoside triphosphate (dNTP), $5 \mu \mathrm{mol} / 1$ random primers, 20 units RNase inhibitor and 50 units avian myeloblastosis virus reverse transcriptase (Perkin Elmer Cetus, Emeryville, Calif., USA). The PCR step was conducted on $5 \mu$ l of the prepared cDNA in $9 \mathrm{mmol} / 1 \mathrm{TRIS} \mathrm{HCl} \mathrm{pH} 8.3,45 \mathrm{mmol} / \mathrm{l} \mathrm{KCl}, 2 \mathrm{mmol} / \mathrm{l}$ $\mathrm{MgCl}_{2}, 100 \mu \mathrm{mol} / \mathrm{l} \mathrm{dNTP,} 20$ pmoles of the 3'- and 5'-primers and 2.5 units of $T a q$ polymerase (Perkin Elmer). Specific primers were designed to anneal with codons 199-206/422-429 for the published sequence of the human liver glucagon receptor [27], codons 203-209/424-431 for the human GLP-1R [25] and codons 195-202/377-384 for the human GIP-R [26], yielding products with expected length $(689,684$ and 568 bp respectively). We used B-actin primers, designed to anneal with codons 249-255/388-244 of human $\beta$-actin (gene accession number NM001101) as an internal control to evaluate RNA quality. The cycling profile for amplification of GIP-R, GLP-1R and glucagon-receptor cDNAs started with a single denaturation step $\left(2.5 \mathrm{~min}, 94^{\circ} \mathrm{C}\right)$ followed by 35 cycles of $(0.5 \mathrm{~min}$, $94^{\circ} \mathrm{C} ; 0.5 \mathrm{~min}, 60^{\circ} \mathrm{C}$ and $0.5 \mathrm{~min}, 72^{\circ} \mathrm{C}$ ) each. The cycling profile for $\beta$-actin was the same except for the annealing temperature, which was $57^{\circ} \mathrm{C}$. We controlled PCR products for their length on a $1.5 \%$ agarose gel and sequenced on an ABI Prism 310 automatic sequencer (Perkin Elmer).

Northern blots were done with $20 \mu \mathrm{g}$ total RNA per sample (fresh human islet cells, human pancreatic duct cells, total pancreas and control tissues from human cadavers) and $1.5 \%$ agarose gels. The RNA was transferred to nylon membranes (GeneScreen, NEN Dupont, Boston, Mass., USA) according to a modified GeneScreen protocol, i. e. we used a phosphate buffer for RNA transfer instead of $2 \times$ SSC. Blots were UVcross-linked (UV StratalinkerTM1800, Stratagene, La Jolla, Calif., USA) and hybridised with ${ }^{32}$ P-labelled cDNA glucagon receptor, GLP-1R, GIP-R and secretin-receptor probes that had been prepared by RT-PCR and that were validated for their nucleotide sequence by automated sequencing. The 
Table 1. Effect of glucagon, GLP-1 and GIP on insulin release from human islet cells

\begin{tabular}{lll}
\hline $\begin{array}{l}\text { Glucose } \\
(\mathrm{mmol} / \mathrm{l})\end{array}$ & $\begin{array}{l}\text { Peptide added } \\
(10 \mathrm{nmol} / \mathrm{l})\end{array}$ & $\begin{array}{l}\text { Insulin release } \\
(\% \text { of insulin content per } 2 \mathrm{~h})\end{array}$ \\
\hline 2.5 & - & $3.8 \pm 0.9^{\mathrm{a}}$ \\
10 & - & $12.6 \pm 2.1$ \\
10 & GLP-1 & $23.9 \pm 5.1^{\mathrm{a}}$ \\
10 & GIP & $23.2 \pm 2.9^{\mathrm{a}}$ \\
10 & Glucagon & $21.0 \pm 3.1$ \\
\hline
\end{tabular}

Data represent mean values \pm SEM of five experiments. Statistical significance of differences in release with $10 \mathrm{mmol} / \mathrm{l}$ glucose alone was calculated by ANOVA. ${ }^{a} p<0.05$

PCR fragments obtained were purified on QIAquick PCR purification columns (Westburg, Leusden, The Netherlands) and served as a template in a random labelling method (Amersham Life Science, Amersham, UK). After hybridisation, blots were stringently washed by incubating for $30 \mathrm{~min}$ at $60^{\circ} \mathrm{C}$ in $0.5 \times \mathrm{SSC}$ and $2.5 \%$ SDS; membranes were stripped and reused for hybridisation with an $18 \mathrm{~S}$ rRNA probe (5'-CTT CCT CTA GAT AGT CAA GTT CGA CCG TCT-3'; Medline accession number K034325) to assess quantity and quality of blotted RNA. Autoradiographic exposure times used for this study were 1 day (glucagon-receptor and GLP-1R transcripts), 2 days (GIP-R mRNA), 5 days (secretin-receptor mRNA) and $1 \mathrm{~h}$ (18S probe). All experiments were repeated at least twice, giving similar results.

Statistical analysis. Insulin release data are expressed as mean values \pm SEM of at least three independent experiments. Significance of differences between controls and experimental conditions was assessed via ANOVA, using $p$ less than 0.05 as the accepted level of significance.

\section{Results}

Measurements of insulin release. Glucagon-like peptide-1, GIP and glucagon were tested for their effects on insulin release in the presence of $10 \mathrm{mmol} / \mathrm{lglu}$ cose (Table 1). During a 2-h static incubation at this glucose concentration, human islets released 3.5 -fold more insulin than at $2.5 \mathrm{mmol} / 1$ glucose $(p<0.05)$. Glucose stimulation was amplified two-fold by 10 $\mathrm{nmol} / \mathrm{l}$ of GLP-1 or GIP (Table 1 ) and $65 \%$ to $85 \%$ by $10 \mathrm{nmol} / \mathrm{l}$ glucagon (Table 1, Fig. 1). To investigate whether the glucagon effect on insulin secretion is mediated by glucagon receptor or GLP-1R or both [28], we tested the potentiating effect of $10 \mathrm{nmol} / \mathrm{l}$ glucagon in the presence or absence of the glucagonreceptor antagonist, des-His ${ }^{1}-\left[\mathrm{Glu}^{9}\right]$-glucagon-amide, or the GLP-1R antagonist, exendin-(9-39)-amide (both at $1 \mu \mathrm{mol} / \mathrm{l}$ ). We found des-His ${ }^{1}-\left[\mathrm{Glu}^{9}\right]$-glucagon-amide did not affect insulin release at $2.5 \mathrm{mmol} / \mathrm{l}$ but the peptide suppressed it at $10 \mathrm{mmol} / \mathrm{l}$ glucose by $50 \%(p<0.05)$ so that the presence of high glucose was no longer stimulatory in this condition (Fig.1). On the contrary, $1 \mu \mathrm{mol} / 1$ exendin-(9-39)-amide did not affect insulin release at $10 \mathrm{mmol} / \mathrm{l}$ glucose (data not shown). To verify that des-His ${ }^{1}-\left[\mathrm{Glu}^{9}\right]$-glucagon-

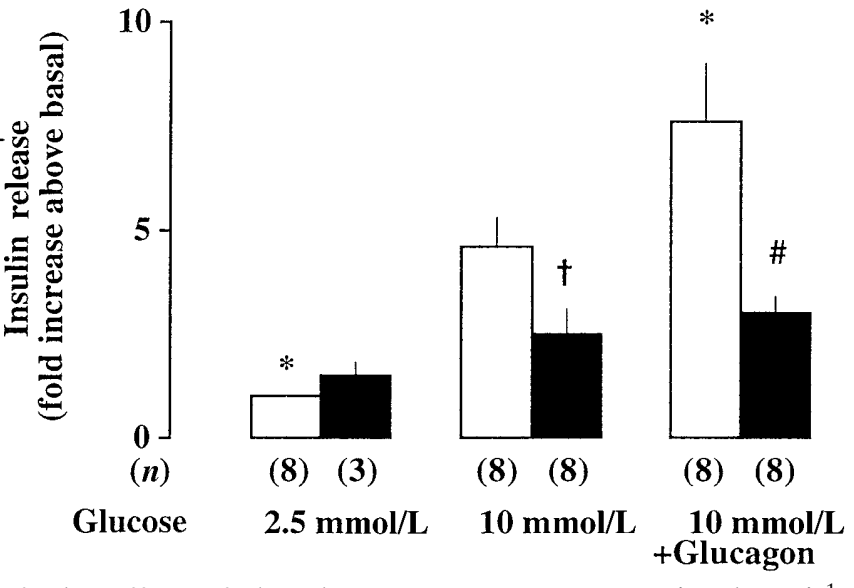

Fig.1. Effect of the glucagon-receptor antagonist des-His ${ }^{1}$ $\left[\mathrm{Glu}^{9}\right]$-glucagon-amide on glucose-induced and glucagoninduced insulin release from human islet cells. Insulin release was measured during 2-h incubations at either $2.5 \mathrm{mmol} / \mathrm{l} \mathrm{glu}-$ cose, $10 \mathrm{mmol} / 1$ glucose or $10 \mathrm{mmol} / 1$ glucose together with 10 $\mathrm{nmol} / \mathrm{l}$ glucagon either in the absence $(\square)$ or presence $(\square)$ of $1 \mu \mathrm{mmol} / 1$ des-His ${ }^{1}-\left[\mathrm{Glu}^{9}\right]$-glucagon-amide. Data represent mean $\% \pm \mathrm{SEM}$ of stimulation over basal release at $2.5 \mathrm{mmol} / \mathrm{l}$ glucose of three to eight independent experiments. Versus $10 \mathrm{mmol} / 1$ glucose alone: $*=p<0.01$. With des-His ${ }^{1}-\left[\mathrm{Glu}^{9}\right]$ glucagon-amide vs without des-His ${ }^{1}-\left[\mathrm{Glu}^{9}\right]$-glucagon-amide: $\dagger=p<0.05 ; \#=p<0.001$

amide acts on human islets as a glucagon-receptor antagonist, we studied its effect on glucagon potentiation of $10 \mathrm{mmol} / \mathrm{l}$ glucose-induced release. Although glucagon potentiation of $10 \mathrm{mmol} / 1$ glucose-induced release was clearly present $(p<0.05)$, it was completely absent in the presence of des-His ${ }^{1}-\left[\mathrm{Glu}^{9}\right]$-glucagon-amide. Together, these data suggest that signalling of the human islet glucagon receptor not only mediates the potentiating effect of exogenously added glucagon but also, by the presence of endogenous glucagon, allows a permissive effect on insulin release from isolated islets.

\section{$m R N A$ analysis}

Because of the restricted amount of cells available, we screened RNA from human islet cells for expression of GLP-1R, GIP-R and glucagon-receptor gene by semi-quantitative RT-PCR, using primer sets corresponding to the published sequences of the human receptors [25-27]. All four human islet cell preparations tested consistently expressed GLP-R, GIP-R and glucagon receptor as evidenced by the PCR fragments of the expected length (Fig. 2) and nucleotide sequence (data not shown). The $689 \mathrm{bp}$ cDNA fragment corresponding to codons 199-429 of the human glucagon-receptor gene [27] was also amplified from human liver but not from lung, adipose tissue or adrenal gland. The amplified fragment which was identical to codons 203-431 of the GLP-1R cDNA [25], 


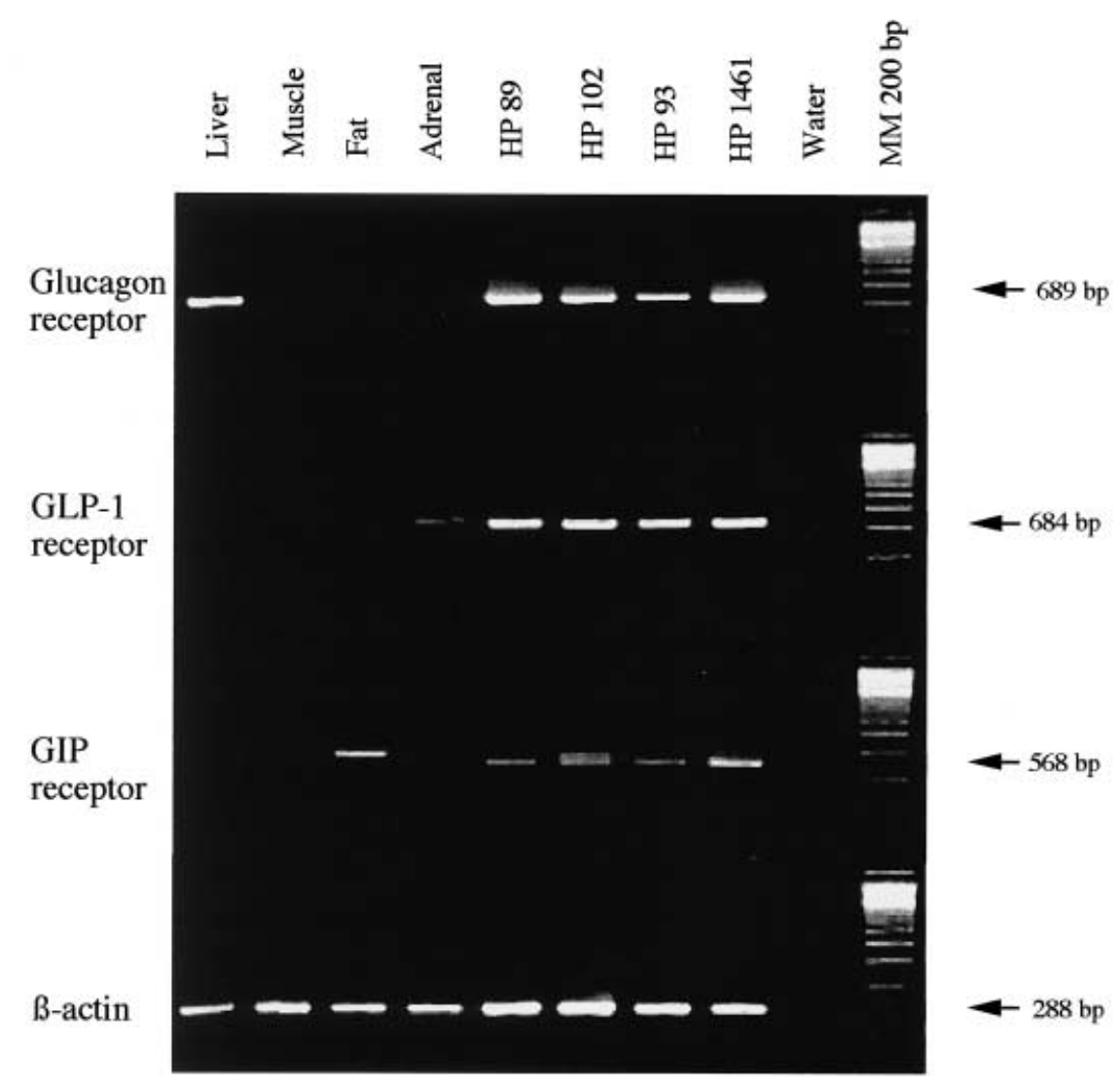

Fig. 2. RT-PCR analysis of mRNA-encoding glucagon receptors, GLP-1 receptors and GIP receptors in human pancreatic islets. Messenger RNA was reverse transcribed and amplified as described in Materials and methods. Total RNA extracted from four different human pancreata (HP89-HP1461) and control tissues was processed in parallel. Fat $=$ abdominal wall adipose tissue; Adrenal = adrenal cortex. Water was taken as negative control for the RT-PCR assay. Right lane: 200-bp molecular weight marker (MM $200 \mathrm{bp}$ )

was present not only in islets but also weakly visible in cDNA amplified from adrenal cortex. Finally, a cDNA fragment corresponding codons 195-384 of the GIP-R [26] was amplified from all human islet samples tested. More than one abundant PCR product for the GIP-R was present in one out of the four human islet cell preparations tested (HP102 in Fig. 2) but the sequence of the additional fragments is not known. In adrenal cortex as well as in liver very weak signals for amplicon(s) were present, but in adipose tissue the abundance of the amplified fragment was much stronger.

Sequence analysis of the adipocyte GIP-R fragment showed a variant in which a 61-bp segment corresponding to exon 8 of the gene was spliced out, encoding a truncated protein with a stop codon within a region corresponding to the fourth transmembrane helix (Fig. 3). Unexpectedly, the shorter cDNA fragment from adipocytes had an abnormal (sligthly slower) electrophoretic mobility than the full length transcript.

Although each of the four human islet cell preparations tested clearly expressed glucagon receptor, GLP-1 and GIP receptors, one point of concern using the RT-PCR approach was that the positive signals might originate from transcripts expressed in non-endocrine cells present in these preparations, notably duct cells which cannot be fully separated from the endocrine cells with the current methods [17]. We therefore compared glucagon-receptor, GLP-1R and GIP-R mRNA abundance in human islet cells with purified duct cells [29] or total pancreas by northern blotting, a less sensitive technique than RT-PCR. Furthermore, with the same methods we assessed secretin-receptor gene expression as this receptor is known to be present on duct cells [31]. Human islet RNA strongly hybridised with the glucagon-receptor, GLP-1R and GIP-R cDNA probes but RNA extracted from duct cells was negative (Fig.4). Conversely, northern blots using the secretin cDNA probe were strongly positive for duct-cell RNA (Fig. 4B).

\section{Discussion}

Three decades ago, Cerasi and Luft applied the Sutherland model for cAMP-dependent signal transduction in mammalian cells [32] to the process of glucose regulation of the pancreatic beta cell and proposed 


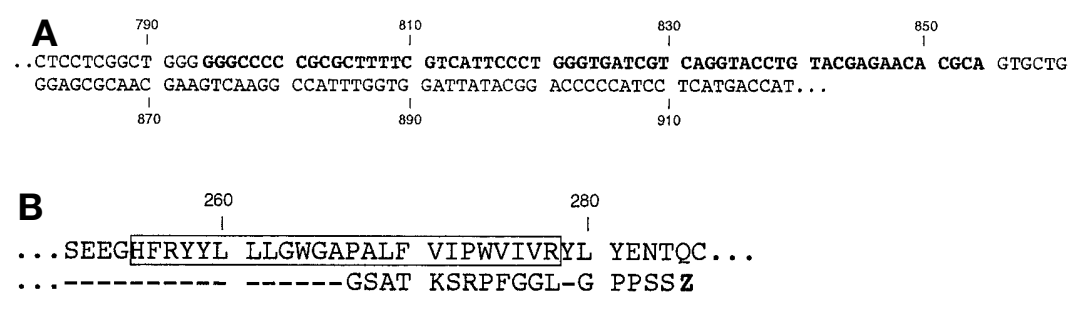

Fig. 3 A, B. Comparison of GIP-R transcripts in pancreatic islets and adipose tissue. Alignment of GIP-R nucleotide sequence (A) and predicted amino-acid sequence (B) corresponding to the amplified and sequenced fragments (see Fig.2) from human islets and adipose tissue. A The spliced out 61-bp nucleotide sequence corresponding to exon 8 of the GIP-R cDNA fragment sequenced from human adipocytes is indicated in bold lettering. B The predicted amino-acid sequence encoded by the full-length islet transcript (upper line) and human adipocyte transcript (lower line) start to deviate from each other within the transmembrane domain 4 (boxed sequence). $\mathrm{Z}$ corresponds to a new stop codon in the truncated protein

that one pathophysiological mechanism of diabetes proceeds by loss of glucose-induced insulin release secondary to impaired signalling in beta cells [18]. Although it is now clear that direct glucose signalling is primarily metabolic $[19,20,33-35]$, i.e. not mediated by $G$ protein-coupled membrane receptors, the idea that normal glucose responsiveness of islet beta cells depends on sufficient intracellular production of cAMP is still a focus of interest. The concept has been supported by various in vitro models of isolated rodent beta-cell preparations [36-38]. First, rat islets isolated from the dorsal, glucagon-rich, pancreas had a better insulin response to glucose than islets taken from the ventral lobe [36], suggesting that paracrine glucagon up-regulated glucose responsiveness of beta cells. Second, flow-sorted and purified rat beta cells which are separated from their neighbouring glucagon-producing alpha cells [37], have a poor secretory response to glucose [1], despite their normal rates of glucose metabolism [33, 39] and glucose-induced insulin biosynthesis [40]. This selective secretory "deficiency" was corrected by adding glucagonin nanomolar concentrations to the cells [1] which increased intracellular cAMP concentrations to the values observed in isolated islets [2]. We therefore proposed that the exquisite glucose responsiveness of intact islets is not only dependent on the process of glucose recognition but also on the presence of a certain threshold of intra-islet glucagon concentration which results in activation of glucagon receptors on beta cells [1-3]. Third, electrophysiological studies [38] have broadened this concept to other peptides of the secretin-glucagon family which can increase cAMP production in beta cells: addition of GLP-1 together with high glucose was necessary for full glu- cose-induced electrical activity in at least a subset of beta cells which were not glucose competent when glucose alone was used as a stimulus.

Analogous to what we have previously reported for the rat [1-4] we now find expression and functional activity of receptors recognising both glucagon and the incretin hormones GLP-1 and GIP in human islets. Furthermore, we observe that by pharmacological inhibition of glucagon-receptor activity using the potent glucagon-receptor antagonist des-His ${ }^{1}-\left[\mathrm{Glu}^{9}\right]$ -

A

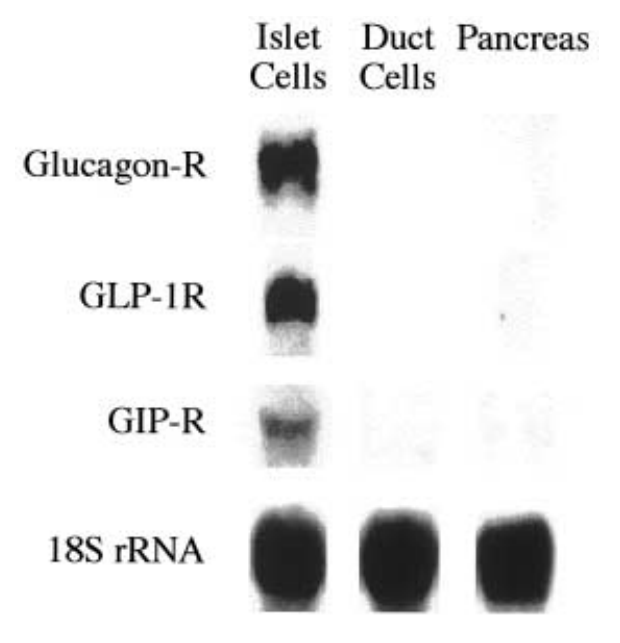

B

$\begin{array}{ll}\text { Islet } & \text { Duct Pancreas } \\ \text { Cells Cells }\end{array}$

Secretin-R

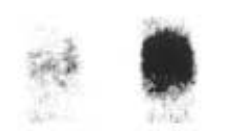

Fig.4A, B. Glucagon-receptor, GLP-1R, GIP-R and secretin mRNA in human islet and duct cells. A Total RNA $(20 \mu \mathrm{g})$ from human islets (lane 1: HP No. 1461), duct cells (lane 2) and total pancreas (lane 3 ) was hybridised with specific probes complementary to cDNA encoding the glucagon-receptor, GLP-1R, and GIP-R. RNA quantity and quality was evaluated by hybridisation signals using a $18 \mathrm{~S}$ probe. Exposure times were 1 day (glucagon-receptor and GLP-1R) and 2 days (GIPR). B RNA $(20 \mu \mathrm{g})$ from one human islet preparation (lane 1: HP No. 1161), purified duct cells (lane 2) and total pancreas (lane 3 ) was blotted and hybridised with a specific secretin-receptor cDNA probe. Exposure time was 5 days. Data are representative for three independent experiments 
glucagon-amide [28] can suppress to a major extent the glucose-responsiveness in these the cells. No such effect was seen with exendin-(9-39)-amide, a potent antagonist of the GLP-1-R [30] which was recently shown to block the incretin effect of GLP-1 in human subjects in vivo [24]. It has been debated, however, whether glucagon secreted from islet alpha cells has direct access to the receptive pole of beta cells [41, 42]. Morphometric data from rat pancreas indicate that arterioles perfusing medium size and large islets branch into capillaries within the betacell core before irrigating insulin-rich blood to the non-beta-cell mantle of the islet and emptying into extra-islet venules [41]. In other words, directionality of blood flow in this species does not favour the idea that glucagon released from alpha cells is preferentially interacting with islet beta cells, although neighbouring beta cells and interactions between alpha and beta cells in very small islets could be a special case. Furthermore, whereas regulation of rodent islet blood flow is relatively well understood [42] little is known about the microcirculation in human islets. Still to be investigated therefore is whether the existence of an important paracrine effect of glucagon, as detected in the present in vitro study, is relevant for the in vivo situation. It is well known from clinical practice that glucagon injection rapidly stimulates insulin secretion, but this is considered a pharmacological effect [13-15]. The possibility that a minimal threshold of paracrine glucagon is required to keep beta cells in a glucose competent state is much more difficult to test in vivo. Studies with glucagon receptor antagonists and mouse models with conditional knockout of the glucagon-receptor gene might be required for further analysis of this problem. Within this context it seems that some patients with Type II (non-insulin-dependent) diabetes mellitus have specific mutations in the glucagon-receptor gene [43] and that the Gly40Ser mutation results in an encoded G-protein coupled receptor which is more resistant to glucagon-induced cAMP formation [44], indirectly suggesting that the hypothesis formulated by Cerasi and Luft [18] could have a clinical correlate for the same receptor as was studied by Sutherland [32]. The present data could also be relevant for drug development in Type II diabetes based on glucagon-receptor antagonism at the level of liver glucagon action.

When screening a number of control tissues for the expression of receptors of the secretin-glucagon family, we observed that human adipose tissue expressed a splice variant of the full-length GIP-R mRNA in which the 61-bp segment corresponding to exon 8 of the gene has been deleted. Of note, this variant seems to be the predominant GIP-R transcript in adipocytes [45], whereas in human insulinoma it was reported to be a minor variant [45]. Rat adipocytes are known to express GIP-R [46]. Structure analysis indicates that a GIP-R-like protein truncated at the level of the pre- dicted fourth transmembrane helix could be sufficient for GIP binding and (at least part of) receptor activity [47] but molecular mechanisms involved in receptor internalisation will probably be disturbed by this truncation [48]. It is not clear, however, to which extent GIP activation of lipolysis in human adipocytes contributes to the metabolic effects of this peptide in humans.

In conclusion, this study showing mRNA expression of glucagon receptors, GIP-Rs and GLP-1Rs in human islet cells correlates well with the measured in vitro effects of glucagon, GIP and GLP-1 on insulin release and the previously described in vivo effects of these peptides in human non-diabetic subjects. The potent effect of the glucagon-receptor antagonist desHis $^{1}$-[Glu ${ }^{9}$-glucagon-amide on glucose competence of insulin release from human beta cells suggests that this receptor could play a part in the control of insulin secretion in humans. Our data further support the idea that cAMP regulates glucose-induced insulin secretion at two levels: (i) ensuring a permissive effect, requiring minimal cyclic nucleotide concentrations, perhaps by local effects on islet glucagon and (ii) potentiating the effects of nutrients such as is observed for the gluco-incretin hormones GLP-1 and GIP.

Acknowledgements. The authors thank the technical staff of the department of Endocrinology and Metabolism for isolating and culturing human islet cells, R. De Proft for help with the insulin release measurements, E. Quartier for his contribution to the northern blots and DNA sequencing and Dr. J. Vandekerckhove for providing exendin-(9-39)-amide. This study was supported by grants from the Flemish Fund for Scientific Research (Grant G.0130.99 to F. Schuit and Aspirant Fellowship of P. Huypens), the Belgian Programme on Interuniversity Poles of Attraction initiated by the Belgian State (IUAP IV), the Vrije Universiteit Brussel (Geconcerteerde Onderzoeksactie GOA9-VUB) and the European Community (BIOMED-I BMH1-CT92-0805).

\section{References}

1. Pipeleers DG, Schuit FC, in’t Veld PA et al. (1985) Interplay of nutrients and hormones in the regulation of insulin release. Endocrinology 117: 824-833

2. Schuit FC, Pipeleers DG (1985) Regulation of adenosine 3',5'-monophosphate levels in the pancreatic $\beta$-cell. Endocrinology 117: 834-840

3. Moens K, Heimberg H, Flamez D et al. (1996) Expression and functional activity of glucagon, glucagon-like peptide I, and glucose-dependent insulinotropic peptide receptors in rat pancreatic islet cells. Diabetes 45: 257-261

4. Van Schravendijk CF, Foriers A, Hooghe-Peters EL et al. (1985) Pancreatic hormone receptors on islet cells. Endocrinology 117: 841-848

5. Thorens B, Porret A, Bühler L, Deng SP, Morel P, Widmann C (1993) Cloning and functional expression of the human islet GLP-1 receptor. Diabetes 42: 1678-1682

6. Abrahamsen N, Nishimura E (1995) Regulation of glucagon and glucagon-like peptide- 1 receptor messenger ribo- 
nucleic acid expression in cultured rat pancreatic islets by glucose, cyclic adenosine 3',5'-monophosphate, and glucocorticoids. Endocrinology 136: 1572-1578

7. Yasuda K, Inagaki N, Yamada Y, Kubota A, Seino S, Seino Y (1994) Hamster gastric inhibitory polypeptide receptor expressed in pancreatic islets and clonal insulin-secreting cells: its structure and functional properties. Biochem Biophys Res Commun 205: 1556-1562

8. Weir GC, Mojsov S, Hendrick GK, Habener JF (1989) Glucagonlike peptide I (7-37) actions on endocrine pancreas. Diabetes 38: 338-342

9. Wang JL, Corbett JA, Marshall CA, McDaniel M (1993) Glucose-induced insulin secretion from purified $\beta$-cells. A role for modulation of $\mathrm{Ca}^{2+}$ influx by cAMP- and protein kinase $\mathrm{C}$-dependent signal transduction pathways. J Biol Chem 268: 7785-7791

10. Pederson RA, Satkunarajah M, McIntosh CH et al. (1998) Enhanced GIP secretion and insulinotropic action in Glucagon-like peptide receptor -/- mice. Diabetes 47: 1046-1052

11. Scrocchi LA, Brown TJ, Maclusky N et al. (1996) Glucose intolerance but normal satiety in mice with a null mutation in the glucagon-like peptide 1 receptor gene. Nature Med 2: $1254-1258$

12. Miyawaki K, Yamada Y, Yano H et al. (1999) Dysfunction of GIP/insulin axis and diabetes using GIP receptor deficient mice. Diabetes Metab 25 [Suppl 4]: XII (Abstract)

13. Samols E, Marri G, Marks V (1966) Interrelationship of glucagon, insulin and glucose. The insulinogenic effect of glucagon. Diabetes 15: 855-866

14. Simpson RG, Benedetti A, Grodsky GM, Karam JH, Forsham PH (1968) Early phase of insulin release. Diabetes 17: 684-692

15. Crockford PM, Porte D Jr, Wood FC Jr, Williams RH (1966) Effect of glucagon on serum insulin, plasma glucose and free fatty acids in man. Metabolism 15: 114-122

16. Ashcroft SJ, Bassett JM, Randle PJ (1971) Isolation of human pancreatic islets capable of releasing insulin and metabolising glucose in vitro. Lancet i: $888-889$

17. Ling Z, Pipeleers DG (1996) Prolonged exposure of human beta cells to elevated glucose levels results insustained cellular activation leading to a loss of glucose regulation. J Clin Invest 98: 2805-2812

18. Cerasi E, Luft R (1970) Diabetes mellitus - a disorder of cellular information transmission? Horm Metab Res 2: 246-249

19. De Vos A, Heimberg H, Quartier E et al. (1995) Human and rat beta cells differ in glucose transporter but not in glucokinase gene expression. J Clin Invest 96: 2489-2495

20. Detimary P, Dejonghe S, Ling Z, Pipeleers D, Schuit F, Henquin JC (1998) The changes in adenine nucleotides measured in glucose-stimulated rodent islets occur in beta cells but not in alpha cells and are also observed in human islets. J Biol Chem 273: 33905-33908

21. Gutniak M, Orskov C, Holst JJ, Ahrén B, Efendic S (1992) Antidiabetogenic effects of glucagon-like peptide-1 (7-36)amide in normal subjects and patients with diabetes mellitus. New Engl J Med 326: 1316-1322

22. Nauck MA, Bartels E, Orskov C, Ebert R, Creutzfeldt W (1993) Additive insulinotropic effects of exogenous synthetic human gastric inhibitory polypeptide and glucagonlike peptide-1(7-36) amide infused at nearphysiologial insulinotropic hormone and glucose concentrations. J Clin Endocrinol Metab 76: 912-917

23. Crockett SE, Cataland S, Falko JM, Mazzaferri EL (1976) The insulinotropic effect of endogenous gastric inhibitory polypeptide in normal subjects. $\mathrm{J}$ Clin Endocrinol Metab 42: 1098-1103

24. Edwards CM, Todd JF, Mahmoudi M et al. (1994) Glucagon-like peptide 1 has a physiological role in the control of postprandial glucose in humans: studies with the antagonist exendin 9-39. Diabetes 48: 86-93

25. Dillon JS, Tanizawa Y, Wheeler MB et al. (1993) Cloning and functional expression of the human glucagonlike peptide-1 (GLP-1) receptor. Endocrinology 133: 1907-1910

26. Gremlich S, Porret A, Hani EH et al. (1995) Cloning, functional expression and chromosomal localization of the human pancreatic islet glucose-dependent insulinotropic polypeptide receptor. Diabetes 44: 1202-1208

27. Lok S, Kuijper JL, Jelinek LJ et al. (1994) The human glucagon receptor encoding gene: structure, cDNA sequence and chromosomal localization. Gene 140: 203-209

28. Moens K, Flamez D, Van Schravendijk C, Ling Z, Pipeleers D, Schuit F (1998) Dual glucagon recognition by pancreatic beta-cells via glucagon and GLP-1 receptors. Diabetes 47: 66-72

29. Lefebvre VH, Otonkoski T, Ustinov J, Huotari MA, Pipeleers DG, Bouwens L (1998) Culture of adult human islet preparations with hepatocyte growth factor and $804 \mathrm{G}$ matrix is mitogenic for duct cells but not for beta-cells. Diabetes 47: 134-137

30. Ulrich CD 2nd, Wood P, Hadac EM, Kopras E, Whitcomb DC, Miller LJ (1998) Cellular distribution of secretin receptor expression in rat pancreas. Am J Physiol 275: G1437-G1444

31. Sutherland EW, Robison GA (1969) The role of cyclic AMP in the control of carbohydrate metabolism. Diabetes 18: 797-819

32. Schuit F, De Vos A, Farfari S et al. (1997) Metabolic fate of glucose in purified islet cells. Glucose-regulated anaplerosis in beta cells. J Biol Chem 272: 18572-18579

33. MacDonald MJ (1990) Elusive proximal signals of betacells for insulin secretion. Diabetes 39: 1461-1466

34. Newgard CB, McGarry JD (1995) Metabolic coupling factors in pancreatic beta-cell signal transduction. Annu Rev Biochem 64: 689-719

35. Trimble ER, Halban PA, Wollheim CB, Renold AE (1982) Functional differences between rat islets of ventral and dorsal pancreatic origin. J Clin Invest 69: 405-413

36. Pipeleers DG, in't Veld PA, Van de Winkel M, Maes E, Schuit FC, Gepts W (1985) A new in vitro model for the study of pancreatic A and B cells. Endocrinology 117: 806-816

37. Holz GG 4th, Kuhtreiber WM, Habener JF (1993) Pancreatic beta-cells are rendered glucose-competent by the insulinotropic hormone glucagon-like peptide-1(7-37). Nature 361: 362-365

38. Gorus FK, Malaisse WJ, Pipeleers DG (1984) Differences in glucose handling by pancreatic A- and B-cells. J Biol Chem 259: 1196-1200

39. Schuit FC, In 't Veld PA, Pipeleers DG (1988) Glucose stimulates proinsulin biosynthesis by a dose-dependent recruitment of pancreatic beta cells. Proc Natl Acad Sci USA 85: 3865-3869

40. Göke R, Fehmann HC, Linn T et al. (1993) Exendin-4 is a high potency agonist and truncated exendin (9-39)amide an antagonist at the glucagon-like peptide 1 (7-36)amide receptor of insulin-secreting $\beta$-cells. J Biol Chem 268: 19650-19655

41. Bonner-Weir S, Orci L (1982) New perspectives on the microvasculature of the islets of Langerhans in the rat. Diabetes 31: 883-889 
42. Jansson L (1994) The regulation of pancreatic islet blood flow. Diabetes Metab Rev 10: 407-416,

43. Hager J, Hansen L, Vaisse C et al. (1995) A missense mutation in the glucagon receptor gene is associated with non-insulin-dependent diabetes mellitus. Nat Genet 9: 299-304

44. Hansen LH, Abrahamsen N, Hager J et al. (1996) The Gly40Ser mutation in the human glucagon receptor gene associated with NIDDM results in a receptor with reduced sensitivity to glucagon. Diabetes 45: 725-730

45. Volz A, Goke R, Lankat-Buttgereit B, Fehmann HC, Bode HP, Goke B (1995) Molecular cloning, functional expression, and signal transduction of the GIP-receptor cloned from a human insulinoma. FEBS Lett 373: 23-29
46. Yip RG, Boylan MO, Kieffer TJ, Wolfe MM (1998) Functional GIP receptors are present on adipocytes. Endocrinology 139: 4004-4007

47. Gelling RW, Wheeler MB, Xue J et al. (1997) Localization of the domains involved in ligand binding and activation of the glucose-dependent insulinotropic polypeptide receptor. Endocrinology 138: 2640-2643

48. Wheeler MB, Gelling RW, Hinke SA et al. (1999) Characterization of the carboxyl-terminal domain of the ratglucose-dependent insulinotropic polypeptide (GIP) receptor. A role for serines 426 and 427 in regulating the rate of internalization. J Biol Chem 274: 24593-24601 